\section{Challenges for conducting blood collection and biochemical analysis in a large multicenter school-based study with adolescents: lessons from ERICA in Brazil}

\author{
Desafios para a coleta de sangue e análise \\ bioquímica em um grande estudo multicêntrico \\ realizado em escolas com adolescentes: lições \\ do ERICA no Brasil
}

Desafíos para la recolección de sangre y el análisis bioquímico en un gran estudio multicéntrico con adolescentes en las escuelas: lecciones del ERICA en Brasil

$\begin{array}{ll}\text { Felipe Vogt Cureau } 1 & \text { Kênia Mara Baiocchi de } \\ \text { Katia Vergetti Bloch } 2 & \text { Carvalho } 10 \\ \text { Aline Henz }{ }^{3} & \text { Laura Augusta Barufaldi 11 } \\ \text { Camila W. Schaan } 1 & \text { Maria Cristina Caetano } \\ \text { Carlos Henrique Klein } 4 & \text { Kuschnir 12 } \\ \text { Cecília Lacroix de } & \text { Moyses Szklo } 2 \\ \text { Oliveira } 5 & \text { Renan Montenegro Jr. }{ }^{13} \\ \text { Denise Tavares Giannini } 6 & \text { Thiago Luiz Nogueira da } \\ \text { Elisa Brosina de Leon } 7 & \text { Silva } 2 \\ \text { Gabriela de Azevedo } & \text { Ulf Ekelund 14 } \\ \text { Abreu } 8 & \text { Beatriz D. Schaan } 1,3\end{array}$

Gabriela Heiden Telo 1

Glauber Monteiro Dias 9

\begin{abstract}
The Study of Cardiovascular Risk in Adolescents (ERICA) is a pioneering study that aimed to assess the prevalence of cardiovascular risk factors, including metabolic syndrome components in Brazilian adolescents. This study aims to describe the methodological aspects related to blood collection as well as to report pertaining results of the preparation, transport, storage, and exams in ERICA. Exams in ERICA were performed in a single laboratory and blood samples were collected in schools in a standardized manner. Logistics involved air transportation of samples to the reference laboratory with controlled temperature since sample collection. The serum was stored in local biorepositories in four centers to be used in future analyses. During the study, 284,247 exams were performed and rate of participation in exams was $56.2 \%$, thus involving 40,732 adolescents. From the total, $92.6 \%$ of the samples reached the reference laboratory maintaining the temperature between $0-10^{\circ} \mathrm{C}$. No clinical significant changes in results due to temperature changes were identified. External quality control recorded satisfactory results in $98.7 \%$ of the evaluations. Four biorepositories with samples of 7,785 adolescents were created. Thus, we can consider that the logistics adopted in ERICA was fairly successful and description of this as well as the difficulties experienced in Brazil can inform and facilitate the planning of future studies, especially in developing countries.
\end{abstract}

Blood Specimen Collection; Clinical Laboratory Techniques; Biological Specimen Banks; Cardiovascular Diseases; Adolescent

\section{Correspondence}

F. V. Cureau

Programa de Pós-graduação em Endocrinologia, Universidade Federal do Rio Grande do Sul.

Rua Ramiro Barcelos 2350, Centro de Pesquisa Clínica, prédio 21, Porto Alegre, RS 90035-003, Brasil.

fvcureau@gmail.com

1 Programa de Pós-graduação em Endocrinologia, Universidade Federal do Rio Grande do Sul, Porto Alegre, Brasil.

2 Instituto de Estudos em Saúde Coletiva, Universidade Federal do Rio de Janeiro, Rio de Janeiro, Brasil.

3 Hospital de Clínicas de Porto Alegre, Universidade Federal do Rio Grande do Sul, Porto Alegre, Brasil.

4 Escola Nacional de Saúde Pública Sergio Arouca, Fundação Oswaldo Cruz, Rio de Janeiro, Brasil.

5 Instituto de Nutrição, Universidade do Estado do Rio de Janeiro, Rio de Janeiro, Brasil.

6 Hospital Universitário Pedro Ernesto, Universidade do Estado do Rio de Janeiro, Rio de Janeiro, Brasil.

7 Instituto de Saúde e Biotecnologia, Universidade Federal do Amazonas, Manaus, Brasil.

8 Instituto de Medicina Social, Universidade do Estado do Rio de Janeiro, Rio de Janeiro, Brasil.

${ }^{9}$ Centro de Tecnologia Celular, Instituto Nacional de Cardiologia, Rio de Janeiro, Brasil.

10 Departamento de Nutrição, Universidade de Brasília, Brasília, Brasil.

11 Departamento de Vigilância de Doenças e Agravos Não Transmissíveis e Promoção da Saúde, Ministério da Saúde, Brasília, Brasil.

12 Núcleo de Estudos da Saúde do Adolescente, Universidade do Estado do Rio de Janeiro, Rio de Janeiro, Brasil.

13 Faculdade de Medicina, Universidade Federal do Ceará, Fortaleza, Brasil.

14 Department of Sports Medicine, Norwegian School of Sports Science, Oslo, Norway. 


\section{Introduction}

Cardiovascular diseases (CVD) are responsible for 30\% of deaths worldwide. The prevention and control of the major risk factors for CVD would theoretically reduce world mortality related to these diseases by half ${ }^{1}$. In Brazil, CVD is the main cause of death and the major contributor to hospitalization costs 2. Complex interactions between behavioral and biological (physiological, biochemical, and inflammatory) risk factors during childhood and especially in adolescence are important in the pathogenesis of atherosclerotic disease, the main CVD in adults 3.

Collection of biological material and biomarkers are important when assessing metabolic disorders in epidemiological studies. A standardized collection of biologic samples poses challenges that include complex storage and transport logistics of biological material in multicenter epidemiological studies. Processes and handling in the pre-analytical phase, for example, may be responsible for $32 \%$ to $75 \%$ of the total variation of results in a laboratory test 4 . In developing countries, conducting this type of study is even more challenging, due to difficulties in importing equipment and laboratory supplies, airway infrastructure issues, and inadequate number of transport routes, all of which make consistent information on biomarkers associated with CVD scarce in these populations.

In Brazil, in addition to the already mentioned difficulties, the continental extension of the country, regional differences, and logistical issues may add even more barriers to biomarker studies. Therefore, the Study of Cardiovascular Risk in Adolescents (ERICA; Estudo de Riscos de Cardiovasculares em Adolescentes in Portuguese) was set up to overcome these barriers. Its objectives were to estimate the prevalence of diabetes, hypertension, and metabolic syndrome, as well as other cardiovascular risk factors in adolescents aged from 12 to 17 years, living in Brazilian cities with more than 100,000 inhabitants. Therefore, the objective of this study was to describe the methodological aspects related to planning and logistics of blood collection, as well as to report the pertaining results of the collection, transport, and storage of blood samples, and exams in ERICA.

\section{Methods}

\section{ERICA's sample design and data collection}

ERICA is a national school-based cross-sectional study. A total of 1,247 (925 with blood collect) schools in 124 municipalities (45.4\% of the possible municipalities) were selected. Data collection was performed between February 2013 and November 2014. The target population was divided into 32 geographic strata: 27 state capitals and five more strata representing other municipalities with more than 100,000 inhabitants in each one of the macro regions of the country.

Schools were selected according to proportional probability for size, which was defined by the ratio of the number of eligible students in the school and the distance between the school and the state capital. Issues such as school location (urban or rural area) and administration (public or private) were also considered. This strategy allowed to center the sample in the vicinity of the capital, which reduced costs and facilitated the logistics of the study, especially concerning blood collection and adequacy of pre-analytical procedures.

In the second sample stage, three classes in each school were selected, considering combinations of the class period (morning or afternoon) and eligible grades (7th, 8th, 9th grades from elementary school and 1st, 2nd, and 3rd grades from high school). All students of randomly selected classes were invited to participate in ERICA, but only students of the morning classes participated in fasting blood collection and only adolescents aged between 12 and 17 years were eligible. Details of ERICA's study design and sampling are available in other studies 5,6.

In summary, the first selected schools were contacted and invited to participate in the study. The students attending the randomly selected classes received information regarding the study. If they agreed to participate, they were registered on the ERICA online system and had their visits scheduled. The data collection in each class was held over two nonconsecutive days; on the first day, a questionnaire was applied using an electronic data collector (Personal Digital Assistant - PDA), anthropometric (weight, height, waist and arm circumference) and blood pressure measurements were taken, and 
a 24-hour dietary recall was conducted. On the second day, a fasting blood sample was collected; as described below. Finally, two weeks after data collection, a member of the research team returned to the schools to deliver the results and conduct a second 24-hour dietary recall in a sub-sample of students. All adolescents who agreed to participate in the study and their parents or legal guardians signed the informed consent forms. ERICA was approved by the local Ethics Research Committee in each of the 27 Federation Units.

\section{Blood collection and logistics: pre-analytical, quality indicators, and analytical care}

ERICA's research protocol was standardized across all 27 centers. For this purpose, it used a single laboratory, in which all biochemical analyses of the study were conducted. The reference laboratory, located in the city of Cascavel (Paraná State), included a network of 60 partner laboratories distributed by ERICA's centers.

In addition to providing the infrastructure that contributed to the completion of the study, the reference laboratory was certified by the National Program of Quality Control (PNCQ; https:// www.pncq.org.br) connected to the Brazilian Society of Clinical Analysis, and by the Program of Accreditation of Clinical Laboratories (PALC; http://www.sbpc.org.br) of the Brazilian Society of Clinical Pathology and Program of Laboratory Indicators (ControlLAB; http://www.control lab.com.br), which has a joint collaboration with the Brazilian Society of Clinical Pathology and Laboratory Medicine.

The reference laboratory identified one or more local partner laboratories in each of the 27 centers to perform the collections of blood samples at schools. All laboratories followed exactly the same protocol throughout the study, from scheduling the blood collection to transportation to the central unit. Each laboratory was informed, via the reference laboratory, about the date, time, and location of the school in which to conduct the blood collection. The charges involving blood collection, transportation, and exams were agreed with the central laboratory as required at baseline by ERICA's coordination.

Around ten days before the blood collection at schools, the central laboratory received a spreadsheet generated by ERICA's web system containing the name and numeric code of students in each enrolled class. This information was used to produce the tube labels with bar codes to allow the linkage of the results of exams with participants' information in the ERICA dataset. Every local laboratory obtained an identical kit for blood collection for each participant from the reference laboratory. The kit was composed of the following materials: four labels with bar code for identification of tubes; a zip bag for sending the samples separately for each participant; a tube with gel for measurements of total cholesterol, HDL cholesterol, triglycerides, and insulin; a fluoridated tube for measurement of glucose and a transport tube for the transfer of aliquot of plasma fluoride; a tube with ethylenediaminetetraacetic acid (EDTA) for measuring glycated hemoglobin (HbA1c); a Pasteur's pipette for aliquot of plasma fluoride; a needle for vacuum collection; and a swab of alcohol for antisepsis of the site of collection and occlusive dressing.

Figure 1 shows the logistics of the data collection in ERICA and the details of the blood collection for biochemical analyses. Blood samples were drawn after at least 12 hours of fasting. To confirm the compliance, a pre-examination questionnaire including questions about time of last food intake, bedtime and wake-up time on the day before the data collection, if any food or liquid was ingested, the use of medication on the day before blood collection (water and medications were allowed) was completed by each participant. For those who did not comply with the 12-hour fasting, a new attempt to collect the blood sample was scheduled appropriately. Additionally, in some specific cases, a direct collection at the local laboratory was offered.

All students were informed about the procedures before the blood samples were drawn and were free to withdraw at any point. First, correct identification was verified with the adolescent. Collection was performed using a vacuum needle for multiple collections, after asepsis of the collection site with alcohol, and a garroting time of less than one minute. After finishing the blood collection, all students received a snack. Industrialized foods were chosen mainly due to the durability of the products, which could be stored for approximately 90 days. The distribution to all Brazil regions was performed by a single company. 
Figure 1

Summary of blood collection, laboratory logistics, and analysis in Study of Cardiovascular Risk in Adolescents (ERICA). Brazil, $2013 / 2014$.

Logistics summary - ERICA

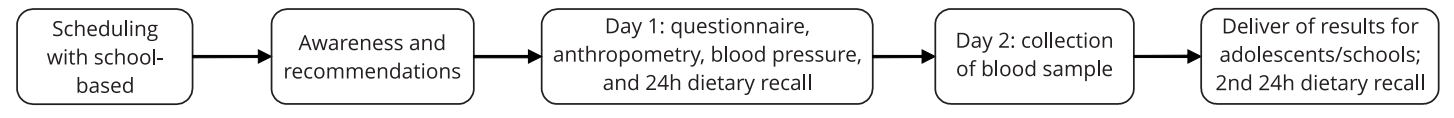

- - - - - - - - - - - - - - - - - - - - - - - - - - - -

Blood collection routine and biochemical analysis

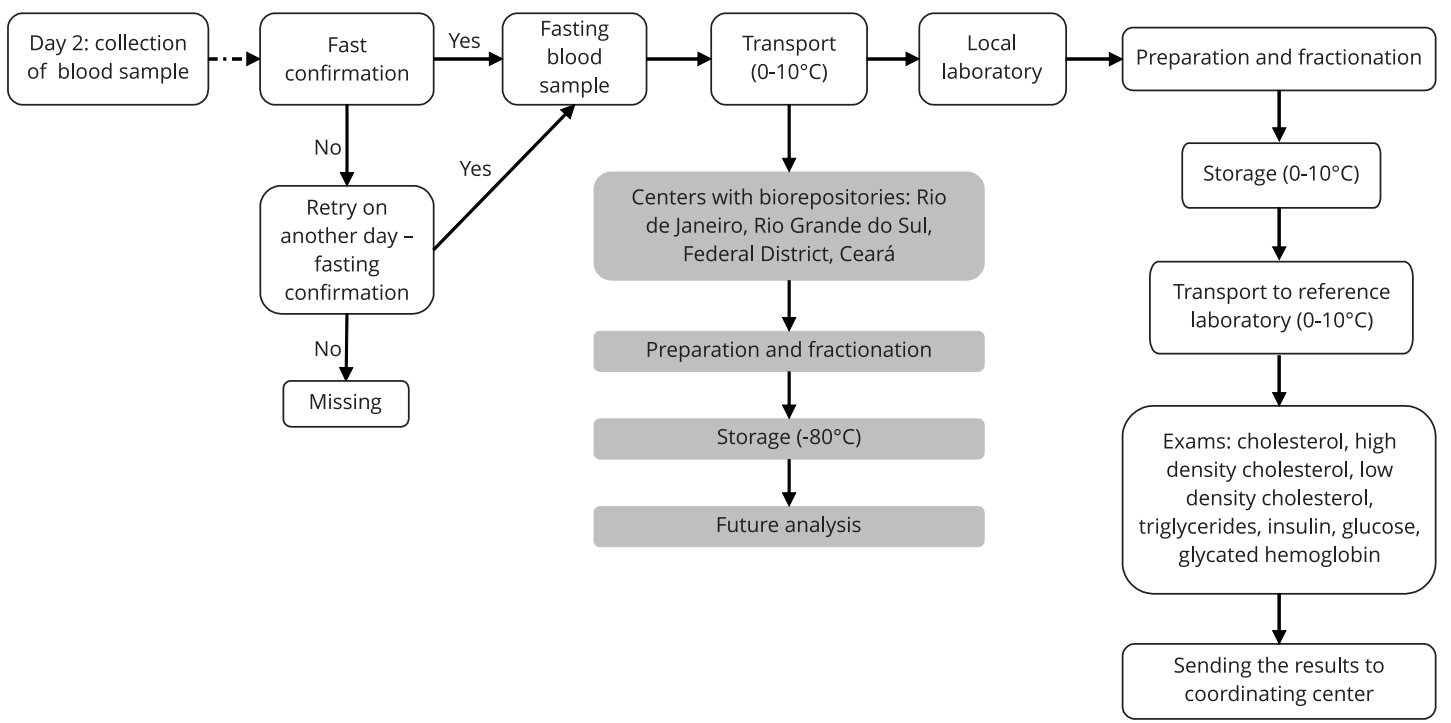

All students provided four tubes, except in the four centers (Rio de Janeiro, Rio Grande do Sul, Federal District, and Ceará). In these centers, two additional gel tubes ( $4 \mathrm{~mL}$ blood per tube) were collected and stored for future analyses.

After homogenization, the tubes were stored in thermal boxes $\left(0-10^{\circ} \mathrm{C}\right)$ before transportation to the local partner and, subsequently, to the reference laboratory. All blood samples were prepared according to a standardized protocol at each local laboratory before transportation to the reference laboratory: gel tubes were centrifuged for 10 minutes at 3,000rpm and then cooled; the primary fluoride tube underwent the same procedure before the plasma was separated and transferred to the transport tube; EDTA tubes were directly refrigerated to maintain the temperature below $10^{\circ} \mathrm{C}$. All samples with pre-analytical problems (e.g. hemolysis) were destroyed at the local laboratory. Samples were packed in bags and then in thermal boxes with dry ice and transported to the reference laboratory by air.

The temperature was checked at three control points: at arrival at the local laboratory site, before transport and finally at the reference laboratory. The samples were kept between $0^{\circ} \mathrm{C}$ and $10^{\circ} \mathrm{C}$ during the entire air routes; samples outside this temperature range were identified and evaluated for the occurrence of clotted, hemolytic, or lipemic samples. Results from samples outside the temperature range were compared with the others in crude analysis (mean and 95\% confidence intervals). The acceptable analytic error by exam was established considering the biological and laboratory variations 7 .

Analyses, methods, and equipment used for dosage, mean coefficient of variation, and cut-off points for each exam are presented in Table 1. Care taken by the reference laboratory in the review 
Table 1

Laboratory analyses performed in Study of Cardiovascular Risk in Adolescents (ERICA). Brazil, 2013/2014.

\begin{tabular}{|c|c|c|c|c|c|c|c|c|}
\hline \multirow[t]{2}{*}{ Exam } & \multirow[t]{2}{*}{ Unit } & \multirow[t]{2}{*}{ Method * } & \multirow[t]{2}{*}{ Equipment } & \multirow{2}{*}{$\begin{array}{l}\text { Coefficient of } \\
\text { variation (\%) }\end{array}$} & \multirow[t]{2}{*}{ Sample (n) ** } & \multicolumn{3}{|c|}{ Cut-off points } \\
\hline & & & & & & Desirable & Borderline & High \\
\hline Glucose & $\mathrm{mg} / \mathrm{dL}$ & Hexoquinase method & $\begin{array}{l}\text { ADVIA } 2400- \\
\text { Siemens }\end{array}$ & 1.54 & 40,555 & $70-99$ & $100-125.9$ & $\geq 12618$ \\
\hline Insulin & $\mathrm{mU} / \mathrm{L}$ & Chemiluminescence & $\begin{array}{c}\text { Modular } \\
\text { Analytics - } \\
\text { Roche }\end{array}$ & 3.58 & 40,576 & $<15$ & $15-20$ & $\geq 2019$ \\
\hline Glycated hemoglobin & $\%$ & $\begin{array}{l}\text { Ion exchange } \\
\text { chromatography }\end{array}$ & G7 - Tosoh & 1.55 & 40,671 & $<5.7$ & - & $\geq 5.718$ \\
\hline Triglycerides & $\mathrm{mg} / \mathrm{dL}$ & Enzymatic kinetics & $\begin{array}{l}\text { ADVIA } 2400- \\
\text { Siemens }\end{array}$ & 1.64 & 40,614 & $<100$ & $100-129$ & $\geq 13020$ \\
\hline Cholesterol & $\mathrm{mg} / \mathrm{dL}$ & Enzymatic kinetics & $\begin{array}{l}\text { ADVIA } 2400- \\
\text { Siemens }\end{array}$ & 1.65 & 40,617 & $<150$ & $150-169$ & $\geq 17020$ \\
\hline LDL-C & $\mathrm{mg} / \mathrm{dL}$ & Friedewald equation & - & - & 40,597 & $<100$ & $100-129$ & $\geq 13020$ \\
\hline HDL-C & $\mathrm{mg} / \mathrm{dL}$ & $\begin{array}{c}\text { Enzymatic colorimetric } \\
\text { assay }\end{array}$ & $\begin{array}{l}\text { ADVIA } 2400- \\
\text { Siemens }\end{array}$ & 2.34 & 40,617 & $\geq 4520$ & - & - \\
\hline
\end{tabular}

HDL-c: high density cholesterol; LDL-c: low density cholesterol.

* Brazilian Society of Pathology;

** Eligible adolescents (12-17 years old).

process included a semi-annual preventive maintenance of equipment to ensure proper performance. All batches were validated when changed, considering the historical value for each exam.

Quantitative internal quality control was evaluated by the coefficient of variation for each analyte according to standard procedures (Clinical Laboratory Improvement Amendments - CLIA; https:// www.cms.gov/clia) and rules of Westgard et al. 8. Also, external controls by ControlLAB and PNCQ programs were periodically conducted for each of the analytes measured in ERICA. Exams with abnormal results were reassessed and results from the two tests compared and reported to the ERICA coordination team. Exams with discrepant values among the analyses were excluded.

Following analyses at the central reference laboratory, all results were sent to the ERICA central coordination center and entered into the ERICA database. All results were thereafter communicated in writing with the participants using a standardized data form. The need for any referrals to a local health service due to the presence of risk factors for CVD (e.g. dyslipidemia, hyperglycemia, or high $\mathrm{HbA1c}$ ) was indicated in this form 5 . If urgent, for example in case of a suspected new diagnosis of diabetes, the ERICA central coordination immediately contacted the local coordinator, who was responsible for contacting the adolescents.

\section{Biorepository}

For adolescents living in the states of Rio de Janeiro, Rio Grande do Sul, Ceará, and Federal District, the serum was stored in local biorepositories to be used in future analyses. All centers with biorepositories had $-80^{\circ} \mathrm{C}$ ultra-freezers for sample conservation, adequate laboratory structure, and trained professionals to perform preparation, separation, identification, and organization of the stored samples.

The two tubes with gel underwent the same standardization already described for other analyses. However, instead of being transported from schools to the local laboratory, they were sent directly to the four research centers. At arrival, samples were centrifuged (10 minutes at 3,000rpm) and the serum was aliquoted into cryotubes pre-identified by bar codes. Thereafter, the samples were fractionated according to the volume of blood, ranging from one to eight cryotubes containing $0.5 \mathrm{~mL}$ of 
each serum. All samples collected at schools were delivered to the research center within two hours and procedures for storage did not exceed four hours. The samples were stored in cryoboxes and organized by school. The position of each sample (row and column in cryoboxes) was inserted into an electronic spreadsheet to facilitate future localization.

\section{Results}

In total, 284,247 exams were performed by the reference laboratory throughout the study, including 40,732 adolescents $(12-17$ years old). Less than $1 \%(n=273)$ of the participants had some missing result. The main reasons for missing samples were insufficient amount of blood (61.2\%), clotted, hemolytic, or lipemic samples (15\%), and samples damaged during transport (14.6\%).

The percentage of blood collection coverage in each center took into consideration for the calculation the total number of eligible adolescents enrolled in ERICA and the final number of students who participated in the blood collection. Overall, 56.2\% ERICA participants also had a blood sample collected, varying from 47.9\% in Mato Grosso do Sul to 69.2\% in Mato Grosso. In centers with biorepositories, the coverage varied from $48.2 \%$ in Rio de Janeiro to $60.6 \%$ in Rio Grande do Sul.

The logistics adopted in ERICA allowed $92.6 \%$ of the blood samples to reach the reference laboratory with the appropriate temperature range $\left(0-10^{\circ} \mathrm{C}\right)$. In 17 of the 27 centers, there was no record of samples with temperatures over $10^{\circ} \mathrm{C}$. The highest proportions samples with temperatures above $10^{\circ} \mathrm{C}$ were recorded in the North region, in the states of Amazonas (43.9\%) and Pará (21.6\%), and in the Northeast region, in Paraíba (19.2\%) and Piauí (16.8\%). Figure 2 shows box-plots for the temperature recorded in each of the centers. The median temperature ranged from $3.0^{\circ} \mathrm{C}$ in the Federal District to $8.0^{\circ} \mathrm{C}$ in Amazonas. The mean blood temperature in ERICA was $6.2^{\circ} \mathrm{C}( \pm 3.3)$ and despite changes in temperature during transportation, no clinically relevant differences were observed when data from the five states with the greatest percentage of samples with abnormal temperature were analyzed (Table 2).

Figure 3 shows the geographic distribution of all cities where blood collection was performed. Considering only one transport between each city enrolled in blood collection and the reference laboratory, around $190,000 \mathrm{~km}$ were covered. The distance of blood transportation varied from $\approx 350 \mathrm{~km}$ from Londrina (state of Paraná) to $\approx 6,500 \mathrm{~km}$ from Macapá (state of Amapá).

Regarding internal laboratory quality control, during the study period, the reference laboratory did not register coefficient of variation values for any of the analytes higher than the threshold value recommended by CLIA, which is below $5 \%$ for all analytes included in ERICA (Table 1). The external quality controls recorded satisfactory results in most instances (98.7\%) and unsatisfactory results in only one (total cholesterol in August 2014).

Finally, four biorepositories were created with serum samples of 7,785 adolescents. In the centers of Rio de Janeiro, Rio Grande do Sul, Federal District, and Ceará: 7,301 (most of the cryotubes with $1 \mathrm{~mL}), 12,719,7,242$, and 9,485 cryotubes with at least $0,5 \mathrm{~mL}$ were stored, respectively. The main problem detected was hemolytic samples, which occurred in $11.4 \%$ of samples stored in Rio de Janeiro, the largest biorepository in ERICA. In this phase, all the collected samples were stored and information about problems as hemolysis will be considered before the future analysis.

\section{Discussion}

ERICA is a pioneer study that aims to evaluate lifestyle factors and cardiovascular biomarkers in adolescents from 27 centers in Brazil, a country of continental dimensions. In spite of the complexity of the logistics used for data collection of the blood specimens, the execution of the study proved to be adequate. The quality control procedures showed satisfactory performance, for all tests. Additionally, a biorepository was created at four different centers and these samples can be used in future studies involving inflammatory, nutritional, and other novel cardiovascular disease biomarkers.

Considering a decline in the participation rates in epidemiological studies in the last decades 9 , $72.9 \%$ of the adolescents completed ERICA's questionnaire (data not shown), and $56.2 \%$ of those 
Figure 2

Box-plots by center for temperature of blood samples upon arrival in ERICA's reference laboratory. Brazil, 2013/2014.

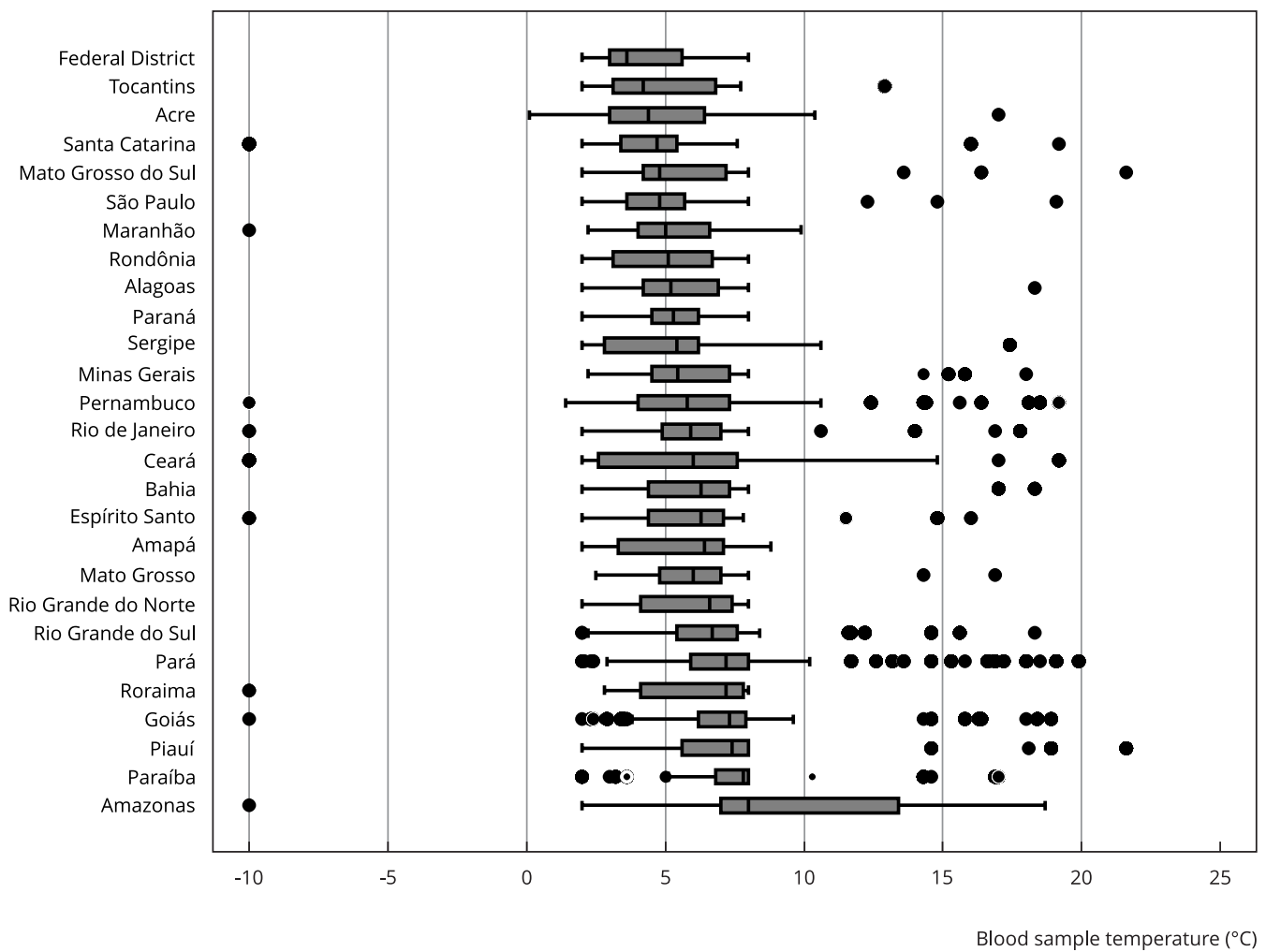

ERICA: Study of Cardiovascular Risk in Adolescents.

eligible for blood samples agreed to participate in this part of the study. This participation rate is satisfactory, as compared to similar studies. In the Swedish part of the European Youth Heart Study, a school-based survey involving blood sampling obtained $49 \%(\mathrm{n}=1,137)$ of participation 10 . In the HELENA study, a school-based study conducted in 10 European cities with adolescents aged from 12 to 17 years, the overall participation rate was $67.1 \%$. However, only one third of the adolescents were eligible for blood collection in that study and response rate was $68 \%(n=1,076) 11$. Despite the relative lower response rate, in ERICA, 70.9\% $(\mathrm{n}=72,508)$ of the adolescents were eligible for blood collection, as they studied during the morning, and 40,732 students participated in the blood sampling.

The collection of biological material and the logistics of ERICA represented a decisive step for the proper assessment and interpretation of results. The centralization of the biochemical analyses in a reference laboratory with strict quality control procedures, assisted by local partner laboratories that managed the field collection, ensured standardization of measures. The centralization of biochemical analyses in a single laboratory has been adopted successfully by large-scale studies in Brazil 4 and abroad 12. However, these studies involved a smaller number of participating centers compared to ERICA.

The strategy to centralize the laboratory tests aimed mainly to guarantee standardization of the methodology used, avoiding the inevitable variations between laboratories. With the care taken in ERICA, the laboratory results were more dependent on issues related to transportation and storage than collection procedures and samples analyses. The guidelines for standardization of actions adhered to by local laboratory partner, to minimize pre-analytical issues, also contributed to the qual- 


\section{Table 2}

Unadjusted analysis comparing results of biochemical exams according to temperature of blood sample in the five centers with higher percentages of samples with abnormal temperature $\left(>10^{\circ} \mathrm{C}\right)$ on arrival at the reference laboratory. Study of Cardiovascular Risk in Adolescents (ERICA), Brazil, $2013 / 2014$.

\begin{tabular}{|c|c|c|c|c|c|c|c|c|c|c|c|c|c|}
\hline & \multicolumn{2}{|c|}{ Amazonas * } & \multicolumn{2}{|r|}{ Pará * } & \multicolumn{2}{|c|}{ Paraíba * } & \multicolumn{2}{|c|}{ Piauí * } & \multicolumn{2}{|c|}{ Goiás * } & \multicolumn{2}{|c|}{ Reference ** } & \multirow{2}{*}{$\begin{array}{l}\text { ATE } \\
\text { (\%) }\end{array}$} \\
\hline & Mean & $95 \% \mathrm{Cl}$ & Mean & $95 \% \mathrm{Cl}$ & Mean & $95 \% \mathrm{Cl}$ & Mean & $95 \% \mathrm{Cl}$ & Mean & $95 \% \mathrm{Cl}$ & Mean & $95 \% \mathrm{Cl}$ & \\
\hline Sample size & 1,625 & & 3,423 & & 1,376 & & 1,329 & & 2,348 & & 7,918 & & \\
\hline$\left(>10^{\circ} \mathrm{C}\right)$ & (689) & & $(740)$ & & $(264)$ & & $(223)$ & & $(231)$ & & (0) & & \\
\hline \multicolumn{14}{|l|}{ Exams } \\
\hline $\begin{array}{l}\text { Choles- } \\
\text { terol (mg/ } \\
\mathrm{dL})\end{array}$ & & & & & & & & & & & 148.9 & 148.3-149.6 & 59.01 \\
\hline $0-10^{\circ} \mathrm{C}$ & 143.8 & $141.7-145.9$ & 146.3 & $145.2-147.5$ & 150.7 & $148.9-152.5$ & 145.2 & $143.3-147.0$ & 149.8 & $148.5-151.2$ & & & \\
\hline$>10^{\circ} \mathrm{C}$ & 140.6 & $138.6-142.3$ & 145.2 & $142.7-147.7$ & 146.3 & $141.7-150.9$ & 148.9 & $145.0-152.7$ & 150.8 & $147.4-154.3$ & & & \\
\hline$\Delta \%$ & 2.23 & & 0.75 & & 2.92 & & 2.48 & & 0.66 & & & & \\
\hline $\begin{array}{l}\text { HDL-c } \\
(\mathrm{mg} / \mathrm{dL})\end{array}$ & & & & & & & & & & & 48.1 & $47.8-48.3$ & 11.63 \\
\hline $0-10^{\circ} \mathrm{C}$ & 45.0 & $44.2-45.7$ & 44.0 & $43.6-44.5$ & 46.1 & $45.4-46.8$ & 45.1 & $44.4-45.8$ & 47.0 & $46.5-47.5$ & & & \\
\hline$>10^{\circ} \mathrm{C}$ & 44.3 & $43.5-45.2$ & 43.5 & $42.8-44.3$ & 43.7 & $42.0-45.4$ & 44.3 & $42.9-45.7$ & 49.4 & $48.0-50.9$ & & & \\
\hline$\Delta \%$ & 1.55 & & 1.14 & & 5.21 & & 1.77 & & 4.85 & & & & \\
\hline $\begin{array}{l}\text { Triglyce- } \\
\text { rides (mg/ } \\
\mathrm{dL} \text { ) }\end{array}$ & & & & & & & & & & & 78.1 & 77.3-78.9 & 25.99 \\
\hline $0-10^{\circ} \mathrm{C}$ & 78.9 & 76.1-81.7 & 83.6 & $81.8-85.5$ & 84.2 & $81.8-86.6$ & 75.6 & $73.5-77.6$ & 79.8 & $78.0-81.5$ & & & \\
\hline$>10^{\circ} \mathrm{C}$ & 77.7 & $74.9-80.5$ & 82.7 & $80.0-85.4$ & 78.8 & $73.5-84.1$ & 75.5 & $70.5-80.4$ & 78.9 & $75.0-82.8$ & & & \\
\hline$\Delta \%$ & 1.52 & & 1.08 & & 6.41 & & 0.13 & & 1.13 & & & & \\
\hline $\begin{array}{l}\text { Glucose } \\
\text { (mg/dL) }\end{array}$ & & & & & & & & & & & 85.9 & $85.7-86.1$ & 6.96 \\
\hline $0-10^{\circ} \mathrm{C}$ & 84.8 & $84.1-85.6$ & 84.2 & $83.9-84.5$ & 86.7 & $86.1-87.4$ & 86.2 & $85.6-86.8$ & 84.3 & $84.0-84.7$ & & & \\
\hline$>10^{\circ} \mathrm{C}$ & 85.3 & $84.7-86.0$ & 85.0 & $84.4-85.6$ & 80.7 & 79.3-82.1 & 86.2 & $85.3-87.2$ & 83.7 & $82.9-84.6$ & & & \\
\hline$\Delta \%$ & 0.59 & & 0.94 & & 6.92 & & 0.01 & & 0.71 & & & & \\
\hline HbA1c (\%) & & & & & & & & & & & 5.36 & $5.35-5.37$ & 3.00 \\
\hline $0-10^{\circ} \mathrm{C}$ & 5.46 & $5.43-5.50$ & 5.43 & $5.42-5.44$ & 5.41 & $5.38-5.44$ & 5.38 & $5.34-5.41$ & 5.38 & $5.36-5.40$ & & & \\
\hline$>10^{\circ} \mathrm{C}$ & 5.40 & $5.37-5.42$ & 5.43 & $5.40-5.46$ & 5.41 & $5.36-5.45$ & 5.41 & $5.36-5.46$ & 5.40 & $5.36-5.44$ & & & \\
\hline$\Delta \%$ & 1.10 & & 0.06 & & 0.07 & & 0.55 & & 0.37 & & & & \\
\hline $\begin{array}{l}\text { Insulin } \\
(\mathrm{mU} / \mathrm{L})\end{array}$ & & & & & & & & & & & 9.79 & $9.64-9.94$ & 32.90 \\
\hline $0-10^{\circ} \mathrm{C}$ & 8.45 & $8.04-8.86$ & 8.88 & $8.60-9.16$ & 7.48 & $7.11-7.84$ & 7.78 & $7.51-8.06$ & 7.55 & $7.27-7.83$ & & & \\
\hline$>10^{\circ} \mathrm{C}$ & 8.81 & $8.16-9.46$ & 8.23 & $7.59-8.88$ & 7.79 & $6.99-8.58$ & 6.68 & $6.13-7.23$ & 6.42 & $5.96-6.88$ & & & \\
\hline$\Delta \%$ & 4.08 & & 7.32 & & 3.98 & & 14.13 & & 14.97 & & & & \\
\hline
\end{tabular}

95\%Cl: 95\% confidence interval; ATE: allowable total error; HbA1c: glycated hemoglobin; HDL-c: high density cholesterol; $\Delta \%$ : difference in percentage between means by categories of temperature.

* Centers with more than $10 \%$ of samples with altered temperatures of blood on arrival at the reference laboratory; highest blood temperature observed were: Amazonas, $17.3^{\circ} \mathrm{C}$; Pará, $19.9^{\circ} \mathrm{C}$; Paraíba, $17.0^{\circ} \mathrm{C}$; Piauí, $21.6^{\circ} \mathrm{C}$; Goiás, $18.9^{\circ} \mathrm{C}$;

** Mean value from the five centers, one from each Brazilian region, without registers of abnormal temperature: Rondônia, Rio Grande do Norte, Federal District, São Paulo and Paraná; In São Paulo, three samples with temperature $>10^{\circ} \mathrm{C}$ were excluded from this analyses.

ity of the biochemical data achieved in ERICA. Furthermore, the initiative of using a pre-examination interview to confirm fasting was important, as it minimized the occurrence of inadequate fasting, which may be a problem in the pre-analytical phase. 


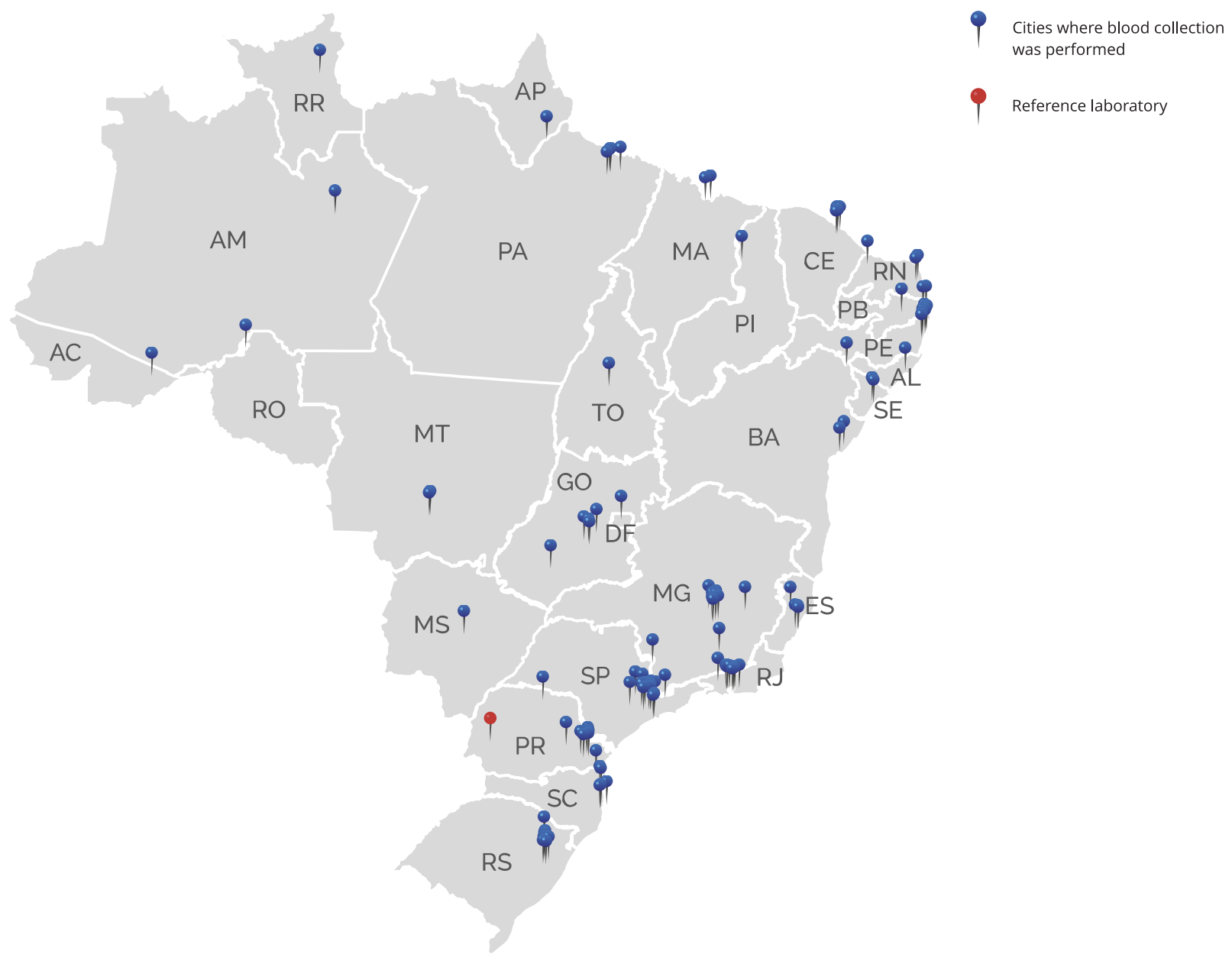

Brazilian Federation Units: AC: Acre; AL: Alagoas; AM: Amazonas; AP: Amapá; BA: Bahia; CE: Ceará; DF: Federal District; ES: Espírito Santo; GO: Goiás; MA: Maranhão; MG: Minas Gerais; MS: Mato Grosso do Sul; MT: Mato Grosso; PA: Pará; PB: Paraíba; PE: Pernambuco; PI: Piauí; PR: Paraná; RJ: Rio de Janeiro; RN: Rio Grande do Norte; RO: Rondônia; RR: Roraima; RS: Rio Grande do Sul; SC: Santa Catarina; SE: Sergipe; SP: São Paulo; TO: Tocantins.

In large-scale studies, logistics to transport biological material is the aspect that deserves especially careful planning, since most of the samples need to be kept in a controlled temperature to preserve their integrity ${ }^{13}$. In ERICA, all steps were carefully monitored to ensure that the samples were maintained between $0^{\circ} \mathrm{C}$ and $10^{\circ} \mathrm{C}$ during the entire process. However, possibly because of the large geographical extent and differences in structure of transport in Brazil, some samples were delivered to the reference laboratory outside this temperature range, although they were all duly identified and evaluated regarding their biological integrity before being analyzed.

The highest incidences of temperatures above the appropriate range were recorded in the North and Northeast regions, areas associated with higher temperatures and longer distances to the reference laboratory. For example, in the five centers with higher rates of sample with altered temperature $\left(>10^{\circ} \mathrm{C}\right.$ ), blood collection was done with ambient temperature around $30^{\circ} \mathrm{C}$ (mean $=29^{\circ} \mathrm{C}$; range $23-37^{\circ} \mathrm{C}$ ). In the South region, most blood samples were collected during autumn and winter seasons 
(mean $=17^{\circ} \mathrm{C}$; range $\left.2-29^{\circ} \mathrm{C}\right)$. The majority of samples from this region were in the expected temperature. Furthermore, in the North and Northeast regions, airplane routes are limited and sometimes it was necessary to use other means of transportation for longer distances, which may have contributed to this result. However, a few hemolytic or lipemic samples were reported. In addition, preliminary comparative analyses did not show important variations in the test results due to temperature changes. It is also important to note that changes in temperature were rare. In the centers of the states of Goiás and Amazonas, temperature of samples changed during transport during 6 and 15 days, respectively, even though the data collection in these places extended more than 90 days.

Time is another important variable to be considered when evaluating sample stability before analysis. Kift et al. 14 examined the effect of storage conditions on sample stability and showed that triglycerides and HDL-c concentrations were increased after 16 hours in room temperature $\left(\approx 20^{\circ} \mathrm{C}\right)$, but total cholesterol concentration remained stable. However, other authors reported that total cholesterol, triglycerides and HDL-c remain stable even after 24 hours up until $30^{\circ} \mathrm{C}$, while glucose concentrations usually decreases progressively after six hours in room temperature 15,16 . However, differences among studies, such as storage conditions, tube types, sample size and differences in the statistical techniques used to define significant change may affect results about stability. In ERICA, we compared the variation among samples in different categories of temperature with allowable total error for each analyte, and results suggest that observed differences were acceptable.

It is well known that there is a need to assess, monitor, and improve all pre-analytical and analytical steps of biomarker measurements in large studies 17, including identification of participants and biological material collected, storage, and transportation of samples 13 . The ERICA study demonstrated that it is viable to carry out blood sampling, transportation, and analyses of cardio-vascular biomarkers on study participants across the entire country. The partnership with local centers allowed proper data collection, transportation, and storage of materials within the pre-established time and under appropriate conditions. The participation rate was satisfactory and the percentage of missing samples was low. It was also possible to store biological material, which will allow future analyses focused on novel biomarkers associated with CVD development. Description of the logistics used during blood collection and the difficulties experienced in the ERICA study can inform and facilitate the planning of future studies, especially in developing countries, where investigators will probably face challenges similar to those found in Brazil. 


\section{Contributors}

F. V. Cureau participated in data collection, led data analysis and article writing, and approved the final version of the paper. K. V. Bloch coordinated the data collection, participated in the data analysis and interpretation and writing of the manuscript, and critically reviewed and approved the final version of the paper. A. Henz, C. W. Schaan, C. L. Oliveira, D. T. Giannini, E. B. Leon, G. A. Abreu, G. M. Dias, K. M. B. Carvalho, and L. A. Barufaldi participated in data collection, and critically reviewed and approved the final version of the paper. C. H. Klein participated in the data collection and interpretation of results, and critically reviewed and approved the final version of the paper. G. H. Telo participated in data collection, article writing, and critically reviewed and approved the final version of the paper. M. C. C. Kuschnir coordinated the data collection, and critically reviewed and approved the final version of the paper. M. Szklo coordinated the data collection, participated in article writing, and critically reviewed and approved the final version of the paper. R. Montenegro Jr. participated in data collection, and critically reviewed and approved the final version of the paper. T. L. N. Silva participated in data collection, collaborated in the data analysis and interpretation, and critically reviewed and approved the final version of the paper. U. Ekelund participated in article writing, and critically reviewed and approved the final version of the paper. B. D. Schaan participated in data collection, collaborated in the interpretation of results and article writing, and critically reviewed and approved the final version of the paper.

\section{Acknowledgments}

F.V.C. is supported by Brazilian Graduate Studies Coordinating Board (Capes) with sandwich Ph.D. scholarship (process: BEX 9556/14-1). K.V.B. (process: 304595/2012-8), B.D.S. (process: 305116/2012-6), and M.S. (process:302877/2009-6) were partially supported by Brazilian National Rsearch Council (CNPq). The authors gratefully acknowledge Maria Inês D’Almeida, from Änima Projetos, for being our consultant. To Brazilian Funding Authority for Studies and Projects (FINEP) and $\mathrm{CNPq}$ for the financial support.

\section{Funding}

ERICA was supported by Science \& Technology Department/Science, Technology and Strategic Inputs Secretariat/Brazilian Ministry of Health (Decit/SCTIE/MS), Health Fund (CT-Saúde)/ Brazilian Ministry of Science, Technology, Innovation and Communication (MCTI) by FINEP (grant: 01090421); CNPq (grants: 565037/2010-2, 405009/2012-7 and 457050/2013-6), and Research Incentive Fund, Hospital of Clinics of Porto Alegre (FIPE-HCPA; register: 09-098).

\section{References}

1. World Health Organization. Global health risks: mortality and burden of disease attributable to selected major risks. Geneva: World Health Organization; 2009.

2. Schmidt MI, Duncan BB, Azevedo e Silva G, Menezes AM, Monteiro CA, Barreto SM, et al. Chronic non-communicable diseases in Brazil: burden and current challenges. Lancet 2011; 377:1949-61.

3. Raitakari OT, Juonala M, Kahonen M, Taittonen L, Laitinen T, Maki-Torkko N, et al. Cardiovascular risk factors in childhood and carotid artery intima-media thickness in adulthood: the Cardiovascular Risk in Young Finns Study. JAMA 2003; 290:2277-83.

4. Fedeli LG, Vidigal PG, Leite CM, Castilhos CD, Pimentel RA, Maniero VC, et al. Logistics of collection and transportation of biological samples and the organization of the central laboratory in the ELSA-Brasil. Rev Saúde Pública 2013; 47 Suppl 2:63-71.

5. Bloch KV, Szklo M, Kuschnir MC, Abreu GA, Barufaldi LA, Klein CH, et al. The Study of Cardiovascular Risk in Adolescents - ERICA: rationale, design and sample characteristics of a national survey examining cardiovascular risk factor profile in Brazilian adolescents. BMC Public Health 2015; 15:94.

6. Vasconcellos MTL, Silva PLN, Szklo M, Kuschnir MCC, Klein CH, Abreu GA, et al. Sampling design for the Study of Cardiovascular Risks in Adolescents (ERICA). Cad Saúde Pública 2015; 31:921-30.

7. Ricos C, Garcia-Lario JV, Alvarez V, Caval F, Domenech M, Hernandez A, et al. Biological variation database, and quality specifications for imprecision, bias and total error (desirable and minimum). The 2014 update. http:// www.westgard.com/biodatabase1 (accessed on May/2016).

8. Westgard JO, Barry PL, Hunt MR, Groth T. A multi-rule Shewhart chart for quality control in clinical chemistry. Clin Chem 1981; 27: 493-501.

9. Galea S, Tracy M. Participation rates in epidemiologic studies. Ann Epidemiol 2007; 17:643-53.

10. Wennlöf AH, Yngve A, Sjöström M. Sampling procedure, participation rates and representativeness in the Swedish part of the European Youth Heart Study (EYHS). Public Health Nutr 2003; 6:291-9.

11. Beghin L, Huybrechts I, Vicente-Rodriguez G, De Henauw S, Gottrand F, Gonzales-Gross $\mathrm{M}$, et al. Main characteristics and participation rate of European adolescents included in the HELENA study. Arch Public Health 2012; 70:14.

12. Sorlie PD, Aviles-Santa LM, WassertheilSmoller S, Kaplan RC, Daviglus ML, Giachello AL, et al. Design and implementation of the Hispanic Community Health Study/Study of Latinos. Ann Epidemiol 2010; 20:629-41. 
13. Plebani M, Sciacovelli L, Aita A, Chiozza ML. Harmonization of pre-analytical quality indicators. Biochem Med (Zagreb) 2014; 24:105-13.

14. Kift RL, Byrne C, Liversidge R, Babbington F, Knox C, Binns J, et al. The effect of storage conditions on sample stability in the routine clinical laboratory. Ann Clin Biochem 2015; 52:675-9.

15. Oddoze C, Lombard E, Portugal H. Stability study of 81 analytes in human whole blood, in serum and in plasma. Clin Biochem 2012; 45:464-9.

16. van Balveren JA, Huijskens MJ, Gemen EF, Pequeriaux NC, Kusters R. Effects of time and temperature on 48 routine chemistry, haematology and coagulation analytes in whole blood samples. Ann Clin Biochem 2016; pii:0004563216665868.
17. Lippi G, Chance JJ, Church S, Dazzi P, Fontana R, Giavarina D, et al. Preanalytical quality improvement: from dream to reality. Clin Chem Lab Med 2011; 49:1113-26.

18. American Diabetes Association. Diagnosis and classification of diabetes mellitus. Diabetes Care 2014; 37 Suppl 1:S81-90.

19. Back Giuliano C, Caramelli B, Pellanda L, Duncan B, Mattos S, Fonseca FH. I guidelines of prevention of atherosclerosis in childhood and adolescence. Arq Bras Cardiol 2005; 85 Suppl 6:4-36.

20. Xavier HT, Izar MC, Faria Neto JR, Assad $\mathrm{MH}$, Rocha VZ, Sposito AC, et al. V Brazilian guidelines on dyslipidemias and prevention of atherosclerosis. Arq Bras Cardiol 2013; 101 (4 Suppl 1):1-20. 


\section{Resumo}

$O$ Estudo de Riscos de Cardiovasculares em Adolescentes (ERICA) é um estudo pioneiro que tem como objetivo avaliar a prevalência de fatores de risco cardiovascular, incluindo componentes da síndrome metabólica, entre adolescentes brasileiros. Este artigo tem como objetivo descrever os aspectos metodológicos relacionados com a coleta de sangue, assim como informar os resultados da preparação, transporte, armazenamento e exames no ERICA. Os exames foram realizados em um único laboratório e as amostras de sangue foram coletadas de forma padronizada. A logística envolveu o transporte aéreo das amostra até o laboratório de referência, com a temperatura controlada desde a coleta do sangue. O soro foi armazenado em biorrepositores locais em quatro centros e se serão utilizados em análises futuras. Durante o estudo foram realizados 284.247 exames e a taxa de participação foi de 56,2\%, representando 40.732 adolescentes. Do total, 92,6\% das amostras chegaram ao laboratório de referência mantendo a temperatura entre $0-10^{\circ} \mathrm{C}$. Não foram identificadas alterações clínicas significativas nos resultados devido a mudanças de temperatura. O controle de qualidade externo registrou resultados satisfatórios em 98,7\% das avaliações. Foram criados quatro biorrepositores com amostras de 7.785 adolescentes. Assim, podemos considerar que a logística adotada no ERICA foi bastante exitosa e sua descrição, tal como as dificuldades experimentadas no Brasil, podem informar e facilitar o planejamento de futuros estudos, especialmente nos países em desenvolvimento.

Coleta de Amostras Sanguíneas; Técnicas de Laboratório Clínico; Bancos de Espécimes Biológicos; Doenças Cardiovasculares; Adolescente

\section{Resumen}

El Estudio de Riesgos Cardiovasculares en Adolescentes (ERICA) es un estudio pionero que tiene como objetivo evaluar la prevalencia de factores de riesgo cardiovascular, incluyendo componentes del sindrome metabólico en adolescentes brasileños. Este estudio tiene como objetivo describir los aspectos metodológicos relacionados con la recolección de sangre, así como informar sobre los resultados de la preparación, transporte, almacenamiento y exámenes en el ERICA. Los exámenes en ERICA se realizaron en un solo laboratorio $y$ se recogieron muestras de sangre en las escuelas de manera estandarizada. La logística involucró el transporte aéreo de muestras al laboratorio de referencia con temperatura controlada desde la recolección de muestras. El suero fue almacenado en biorepositories locales en cuatro centros que se utilizarán en análises futuros. Durante el estudio se realizaron 284.247 exámenes y la tasa de participación fue de 56,2\%, lo que involucró a 40.732 adolescentes. Del total, el 92,6\% de las muestras alcanzaron el laboratorio de referencia manteniendo la temperatura entre $0-10^{\circ} \mathrm{C}$. No se identificaron cambios clinicos significativos en los resultados debido a cambios de temperatura. El control de calidad externo registró resultados satisfactorios en el 98,7\% de las evaluaciones. Se crearon cuatro biorrepositores con muestras de 7.785 adolescentes. Así, podemos considerar que la logística adoptada en el ERICA fue bastante exitosa y su descripción así como las dificultades experimentadas en Brasil pueden informar y facilitar la planificación de futuros estudios, especialmente en los países en desarrollo.

Recolección de Muestras de Sangre; Técnicas de Laboratorio Clínico; Bancos de Muestras Biológicas; Enfermedades Cardiovasculares; Adolescente
Submitted on $14 / \mathrm{Jul} / 2016$

Final version resubmitted on 22/Nov/2016

Approved on 06/Jan/2017 